\title{
Debt Capital and Financial Performance: A \\ Comparative Analysis of South African and Sri Lankan Listed Companies
}

\author{
D.K.Y. Abeywardhana \\ Department of Accountancy, University of Kelaniya, Sri Lanka \\ E-mail: dilyapa@kln.ac.lk \\ K.M.R.Magoro \\ E-mail: kmr2175@gmail.com
}

Received: July3, 2017 Accepted: October 4, $2017 \quad$ Published: December 1, 2017

doi:10.5296/ajfa.v9i2.11761 URL: https://doi.org/10.5296/ajfa.v9i2.11761

\begin{abstract}
This study compares how the debt capital of the listed companies operating in the wholesale and retail sectors of South Africa and Sri Lanka affect their financial performance. Objective of this study is to examine whether debt capital affects the financial performance of the wholesale and retail sector companies in South Africa and Sri Lanka. To examine the impact of debt financing on financial performance of companies over the 2011-2015 period. Fixed-effects (within) regression model was used.

The findings the study confirms that debt financing, in terms of short-term debt and long-term debt, has a negative impact on the financial performance of wholesale and retail sector companies in the context of South Africa. In Sri Lanka, debt financing, in terms of short-term debt has a negative impact on firm performance, while long-term debt has a positive impact. This study gives special focus to identify in which industries do different components of the capital structure have significant impact or weak-to-no impact on firm performances.
\end{abstract}

This suggests for the South African wholesale and retail sector can use equity capital and retained earnings efficiently, thereby minimizing conflicts of agency or agency costs and remaining independent of external financiers. In the case of Sri Lanka, the owners and 


\section{Macrothink}

Asian Journal of Finance \& Accounting ISSN 1946-052X

managers of the retail companies should consider reducing the use of short-term debt and increase long-term debt capital as long-term debt seems to influence their financial performances positively.

Keywords: Debt capital, Financial performance, South Africa, Sri Lanka; Capital Structure 


\section{Introduction}

Firms of different sizes often have a common problem, which is, deciding on whether to use debt or equity or both to finance their operations. The decision is of extreme importance given the impact it has on firm value and performance. The capital structure of a firm is a specific mix of debt and equity the firm uses to finance its operations (Abor, 2005). There are many alternative capital structures from which the firm can choose. It has the option, if it can, to issue a large amount of debt or very little debt. It can also finance its business operations by means of leasing, issue convertible bonds, use warrants, trade bond swaps or sign forward contracts. The firm can issue a lot of various securities in countless combinations. It is important for the firm however, to find the particular combination of debt and equity that maximizes its overall market value (Abor, 2007). Sharp and practical business managers who are able to identify and bring the appropriate mix of debt and equity into effective action are fully rewarded in the marketplace because this optimum composition of debt and equity minimizes the cost of financing of the firm, all things being equal. Given revenue and pre-financing profit streams that are generated through non-financial factors, minimizing cost of financing maximizes net returns for the firm, thereby improving its competitive advantage in the marketplace (Gleason, Mathur and Mathur, 2000). Gleason et al. (2000) suggested that utilization of different levels of debt and equity in the firm's capital structure is one such firm-specific strategy used by managers in search for improved performance.

The interplay between capital structure and firm performance is a crucial and frequently discussed issue, and has been the subject of many studies. Modigliani and Miller (1958) were the pioneers of this study area, and since then there have been a wide range of contributors that have stretched this supposed solution further. The choice of capital structure (the composition of debt and equity) is greatly linked with firm performance as capital structure is said to play a determinant role in firm profitability. Modigliani and Miller (1958) developed a proposition highlighting the irrelevance of capital structure, thereby hypothesized that in perfect markets, it matters not what capital structure a company uses to finance its operations as a firm's financing choice does not affect its capital cost, value or real operations, including performance. The scholars theorized that the market value of a firm is determined by its earning power and by the risk of its underlying assets, and that its value is independent of the way it chooses to finance its investments or distribute dividends. For this view to hold, Modigliani and Miller (1958) based their proposition on a number of assumptions; for example, that no taxes or transaction costs exist, that both companies and investors have equivalence in borrowing and lending money, that companies and investors have the same market information (symmetry) and that agency costs exist. 'Although Modigliani and Miller (1963) suggested that firms can gain the benefits of tax-deductible interest payments by increasing the amount of debt in their capital structure, this view has been questioned due to its assumption of market perfection and its limited applicability to small firms. Different researchers followed with theories that contributed to the literature. Now there are well-known capital structure theories, which include Pecking Order Theory, Trade-Off, Agency Costs, Corporate taxes, financial distress, and Signalling. 
The capital structure literature is varied with mixed results in different times and locations. However, the few studies (Gleason et al., 2000; Yazdanfar and Öhman, 2015) which have investigated multiple sectors; including wholesale and retail, have found common results. The researchers found that, although the results of the impact of capital structure on firm performance could be mixed in other sectors, the relationship is however negative in the wholesale and retail sector. Different measures have been used in different researches, which led to dissimilar findings. While on the other hand, some researchers from different countries (Ghana - Abor (2005); Sri Lanka - Nirajini and Priya (2013); Malaysia - San and Heng (2011) \&Salim and Yadav (2012); USA - Roden and Lewellen (1995); China - Huang (2006); India - Kakani et al. (2001); etc.), have used similar measures and still found contradicting results, which shows that location of trade for firms could bring about different results from those already found in other studies. It is from these reasons that the motivation of this research is derived.

However, it should be noted that although a large body of supporting empirical evidence is available for most of the developed countries very little research has been conducted in developing countries like South Africa and Sri Lanka, particularly in the currently researched wholesale and retail sector. Most of the previous researches conducted under the capital structure study area (Goddard et al., 2005; Abor, 2005;Nimalathasan and Brabete, 2010; Salim and Yadav, 2012), specifically those that examined the impact of debt and equity mix on firm performance did not incorporate the wholesale and retail sector, with the exception of Gleason et al. (2000) and Yazdanfar and Öhman (2015), who, to the knowledge of the researcher, are the only scholars that studied and examined this impact in the wholesale and retail sector among other sectors.

This study seeks to study comparatively the impact of debt capital on the financial performance of companies operating in the wholesale and retail sectors of South Africa and Sri Lanka. That is done using the Fixed-effects (within) regression model on the accounting measures of profitability and financial performance. This research is interested to see whether the same negative relationship as found by Gleason et al. (2000) and Yazdanfar and Öhman (2015) exists in the Johannesburg Stock Exchange (JSE) and Colombo Stock Exchange (CSE) Listed Companies and to find out the reasons for this negative relationship, particularly because these previous findings were found in researches that included all non-financial institutions industries as opposed to the special focus given to only the Wholesale and Retail industry in this research.

Objective of this study is to examine whether debt capital affects the financial performance of the wholesale and retail sector companies in South Africa and Sri Lanka. The findings of this research will help South African wholesalers and retailers as well as Sri Lankan retail companies to understand the impact of debt capital on company performances. This study will help them make decisions that will ensure profit maximization and reduction of costs associated with debt. Previous researchers have focused on the impact of the entire capital structure (both debt and equity components) of the firms on their performances. The originality of this research is that it seeks to test the impact that the debt component of the capital structure (debt capital) has on the company's financial performance, if there's any 
impact at all. The debt capital will be measured as the ratio of short-term debt and long-term debt. The impact of these debt ratios on the financial performance ratios is what this study seeks to examine. This research was inspired by contradicting findings from different researchers in different industries. It is also in response to Dawar (2014) which suggested that future researchers should incorporate sectoral analysis so as to explore whether relationship is any different given the specific attributes particular to an industry. Gleason et al. (2000) also stated that 'Selecting all firms from one industry ameliorates problems associated with analysis of firms from different industries.'

The rest of the paper is organized as follows. Section 2 discusses the theoretical literature review of capital structure and financial performance. Section 3 presents the research design, hypotheses and methodology employed to address the research questions of the study. It also explains data collection and sampling, as well as the measurement of research variables. Section 4 presents the results of the research, data analysis and the discussion and section 5 presents the conclusions, recommendations and limitations of the study.

Most of the previous researchers have focused on the impact of the entire capital structure (both debt and equity components) of the firms on their performances. The originality of this research is that it seeks to test the impact that the debt component of the capital structure (debt capital) has on the company's financial performance, if there's any impact at all. This supports and extends the work of other researchers (Campello, 2006; Abor, 2007; Eldomiaty and Mohamed, 2008; Sadeghian et al., 2012; Yazdanfar and Öhman, 2015; Moon et al, 2015; Davydov, 2015) that have studied the impact of debt financing on firm performance. As pointed out by Eldomiaty and Mohamed (2008), 'The literature on determinants of capital structure lends itself to firms' debt structure. The literature is rich in research papers that discuss the determinants of capital structure, mostly focusing on using the debt ratio as a proxy for capital structure.'

The other unique factor is that most previous researchers (e.g., Goddard et al., 2005; Campello, 2006; David \&Olorunfemi, 2010; Salim and Yadav, 2012; Sadeghian et al., 2012; Dawar, 2014; Abeywardhana, 2015; Yazdanfar and Öhman, 2015, etc.) have conducted their researches on all non-financial institutions industries (listed or non-listed) together in one study, while this study seeks to research only about the wholesale and retail sector (industry) due to the little amount of research conducted, as well as the negative relationships found by the few researchers on the impact of capital structure on firm performances in this particular industry (Gleason et al., 2000; Yazdanfar and Öhman, 2015).

This study proposes ratios and financial links that have not been used by previous researchers in one study. The study proposes the following ratios to show a direct link between the company's debts (with yearly movements/changes) and its performance in terms of sales and profitability as additional tools to measure the impact of the firm's debt capital on the company's performance, size kept constant:

- Debt Growth Rate vs. Sales Growth Rate

- Debt Growth Rate vs. Profit Growth Rate 
This study seeks to pioneer the addressing of the root causes and reasons of research contradictions in this study area by breaking down the broader areas (i.e. capital structure) into small components that make up the whole study area, and to identify in which industries do different components of the capital structure have significant impact or weak-to-no impact on firm performances.

\section{Literature Review}

The impact of debt financing and financial performance has been the subject of many studies. While most of these studies ignore wholesale and retail sector in favour of manufacturing and other sectors (Goddard et al., 2005; Abor, 2005; Abu-Tapanjeh, 2006; Nimalathasan and Brabete, 2010; Sheikh and Wang, 2011; Salim and Yadav, 2012), the current study highlights the significance of the less researched sector and the importance of location of trade for the companies being researched. In South Africa, according to South Africa's key sectors contribution to Gross Domestic Product (GDP) growth in 2013, wholesale and retail trade contributed $12.5 \%$ to the GDP. That is the fourth largest contributing factor in the country.

Abor (2005) adapted regression analysis to test the relationship between capital structure and performance in terms of profitability among 22 listed firms in Ghana over the 1998-2002 period. The study of Abor (2005) revealed a significantly positive relation between the ratio of short-term debt to total assets and Return on Equity (ROE). On the other hand, Abor (2005) indicated that there was a negative relationship between the ratio of long-term debt to total assets and ROE. Going further, Abor (2007) used a generalized least squares regression to study a sample of 160 Ghanaian and 200 South African Small and Medium Sized Enterprises (SMEs) over the 1998-2003 period. The results of Abor (2007) indicate that capital structure influences financial performance of Ghanaian and South African firms, although not exclusively. On the other hand, Abor (2007) found that by and large, the results indicate that capital structure, especially long-term and total debt ratios, negatively affect performance of SMEs. The two studies show that there was a definite negative relationship between long-term debt ratios and the financial performance of the firm; while the short-term debt ratios impact the firm performance positively.Ebaid (2009) used multiple regression analysis and revealed that capital structure choice decision, in general terms, has a weak-to-no impact on firm's performance.

Booth et al. (2001) found that debt ratios and profitability are negatively correlated for a set of ten developing countries including Brazil, Mexico, South Korea, Zimbabwe and Malaysia among others. American researchers in general have found mixed results in their studies of the impact of debt financing on firm performance. Many show that the use of debt at different levels (high debt financing or low debt financing) would yield different results as far as the debt impact or influence on firm performance is concerned. According to Hadlock and James (2002) American corporations with high level of profitability use high level of debts, citing a positive relationship between debt and profitability only when the level of debt is higher or the other way round.

Mesquita and Lara (2003) study 70 Brazilian industrial and service companies over the 1995-2001 period, employing the Ordinary Least Squares (OLS) method indicated that the 
return rates present a positive correlation with short-term debt and equity, and an inverse correlation with long-term debt. In contrast, Byoun and Xu (2013) reported that large debt-free firms are more profitable than levered firms of similar size. This was backed by Moon et al. (2015) when it was found that zero-debt firms generate positive abnormal returns in the long. This notion takes the contradictions further by indicating that large firms with no debt at all are performing better than their debt-loaded counterparts. This shows that according to these researchers, debt has no impact on profitability or financial performance of the firm when the firm is large. Moon et al. (2015) used Fama and French's (1993) three-factor and Carhart's (1997) four-factor models to examine the subsequent 1, 2, 3, 4 and 5-year stock returns of firms that stayed debt free for 3- and 5-year periods.

Kakani et al. (2001) studied 566 large Indian firms for eight years and divided into two sub-periods (viz., 1992-96, and 1996-2000) to examine the financial performance of Indian firms across various dimensions. The study found that leverage 'again' came out as having a significant negative effect on accounting profitability measures. Leverage ratio proved to have a significant negative effect on shareholder value in both the sub-periods.

In support of Kakani et al.'s (2001) exploratory study, Dawar (2014) used the fixed effect panel regression model to find the relationship between leverage and firm performance after controlling for factors such as size, age, tangibility, growth, liquidity and advertising. The results suggested that leverage has a negative influence on financial performance of Indian firms, which is in contrast with the assumptions of agency theory. Dawar, (2014) incorporated sectoral analysis to explore whether relationship is any different given the specific attributes particular to an industry. This support of what the previous authors, (Williams and Goodman, 1971; Gupta and Huefner, 1972; Bowen et al, 1982; Mensah, 1984), said when it was suggested that applying the same variables across different sector produces overly general models that overlook the specific attributes of the sectors. Sheikh and Wang (2011) used several methods, including OLS, fixed effects and random effects, to study the influence of capital structure on the performance and concluded that long-term and short-term debt ratios are negatively related to ROA.

Sri Lankan researchers have mixed results in terms of the impact of capital structure on profitability with majority finding a positive relationship. Nimalathasan and Brabete (2010) found that Capital structure has a great impact onprofitability performing multiple regression analysis. Nirajini and Priya (2013) adapted a regression model to analyse the extent to which capital structure impacts financial performance of listed companies in Sri Lanka. The empirical research found that firm capital structure has a significant impact on financial performance.

In the case of Jordan, Abu-Tapanjeh (2006) found that a weak relationship existed between some of the independent variable and profitability, except for debt ratio. The author states that 'as far as debt ratio's relation with profitability of the selected Jordanian industrial companies is concerned, there was a significant positive relation during the years 1999-2003 as well as for the pooled sample. 
Sadeghian et al. (2012), study the probable relationship between the performance indicators and debt ratios of Tehran Stock Exchange Companies, using regression model and found that an increase in current debts, non-current debts, and total debts has a negative influence on the corporate performance. Zeitun and Saleh (2015) used a panel data to examine the effect of financial leverage on firm's performance using the dynamic Generalised Method of Moments (GMM) estimator to investigate the effects of financial leverage on firm's performance in Gulf Cooperation Council (GCC) countries. Firms leverage affects their performance significantly and negatively, showing that higher financial leverage in GCC companies' capital structure decreased their performance. This is consistent with Twairesh, (2014),Chinaemerem and Anthony (2012), Gleason et al., (2000)Majumdar and Chhibber (1999).

European studies (Gleason et al., 2000; Goddard et al., 2005; Yazdanfar and Öhman, 2015) have found the relationship between capital structure and company performances to be negative in various sectors. Gleason et al. (2000) and Yazdanfar and Öhman (2015) have studied the 'Wholesale and Retail' sector.

Goddard et al. (2005) estimated a profitability model using a two-step GMM estimator, applicable to data sets with a large cross-sectional and a small time-series dimension. The findings show that profitability was inversely related to the firm's gearing ratio with regards to the European manufacturing and services sectors, but also noted that firms with higher liquidity tend to be more profitable.

Yazdanfar and Öhman (2015) used three-stage least squares (3SLS) and fixed-effects models to analyse a comprehensive, cross-sectoral sample Swedish SMEs operating in five industry sectors during the 2009-2012 period. The study confirmed that debt ratios, in terms of trade credit, short-term debt and long-term debt, negatively affect firm performance in terms of profitability. As a high debt ratio seems to increase the agency costs and the risk of losing control of the firm, SME owners and managers tend to finance their businesses with equity capital to a fairly high degree. In confirmation of the study of Yazdanfar and Öhman (2015), Abeywardhana (2015) found that long-term debt to total assets ratio is negatively related with the profitability of nonfinancial SMEs in the UK. The researcher used the Two Stage Least Squares (2SLS) model to examine the relationship between capital structure and the profitability of non- financial SMEs in the UK for the period of 1998-2008.

Weill (2008) found mixed results that financial leverage, is related to firm performance positively and significantly in Spain and Italy, but negatively and significantly in Germany, France, Belgium and Norway, and negatively and insignificantly in Portugal. Kebewar (2012) underlined that evidence from French service sector shows that debt has no influence on profitability either in a linear way, or in a non-linear way. This study found that even when the analysis is presented using different size classes there is no impact regardless of the size of the enterprise. Using GMM Kebewar (2012) shows that debt ratio has no effect on corporate profitability, regardless of the size of company.

As Abor (2005) concluded, 'there is no universal theory of the debt-equity choice.' This is supported by the above review of the literature which shows contradictions in the findings of 
the many studies conducted in an attempt to find the optimal capital structure which should ensure an increase or improvement in the firm's performance and value. The studies had varying structures, used different measures of firm performance and reported mixed results. The fact that the results were obtained from studies conducted in varying socio-economic contexts, can to some extent explain the contradictions of the results, as the underlying structure, form or nature of the researched institutions may play a role in the relationship between the firm's financial leverage and its financial performance. This is therefore a rational motive (reason) why it is relevant to study this relationship and the impact between these variables (debt financing and firm performance) in both the South African and Sri Lankan contexts. To the best knowledge of the researcher, the wholesale and retail sectors of the two countries have not been studied under the capital structure study area, which is another reason why it is befitting to explore the impact of debt capital on the financial performance of companies in a comparative study between the two countries.

\section{Methodology}

In terms of the research methodology employed, the research applied longitudinal (panel data) research techniques to analyse data across the sampled publicly listed companies for the five year period from 2011 to 2015. Data collection was undertaken using a secondary data method that depended mainly on firms' annual reports. The variables were developed in a manner that gave consistency to prior studies and underlying theories. The variables as well as the hypotheses were measured according to accounting and financial guidelines in order to answer the research questions. Entire dataset is 205 observations (125 from South Africa and 80 from Sri Lanka) which will be analysed separately for a comparative study. Panel data regression models have been employed for the purpose of this study for which Hausman test was conducted and showed support for Fixed-effects (within) regression model.

\subsection{Hypothesis Development}

Agency cost theory affirmed the assertion made by the pecking order theory as it suggests that, conflicts of interest between owners and creditors should likely lead to a negative relationship between financial leverage and profitability.

The agency cost theory adds that profitable firms would tend to decrease their agency costs of debt by using retained earnings and thereby reducing their debt ratios. Based on the agency cost view, the effects of accounts payable, short-term debts and long-term debts on performance in terms of profitability are all likely to be negative (Yazdanfar and Öhman, 2015).

There have been quite a good number of researchers that have conducted their studies based on the above theories, but to date, there's still no determined conclusive relationship between capital structure and financial performance of firms. Campello (2006) found that debt financing may either boost or hinder firm competitive performance as the study conducted suggests that moderate debt taking by a firm may, on the margin, yield market share gains. After some point though, additional indebtedness leads to significant sales underperformance. Gleason et al. (2000) as well as Yazdanfar and Öhman (2015) found that agency conflicts 


\section{Macrothink}

Asian Journal of Finance \& Accounting

ISSN 1946-052X

2017, Vol. 9, No. 2

may be primarily responsible for overleveraging of retailers, resulting in a negative relationship between capital structure and performance. On that basis, the following hypothesis is developed:

H1: Debt capital has a negative impact on the financial performance of the wholesale and retail sector companies in South Africa and Sri Lanka.

H1.1: Short-term debt has a negative impact on the financial performance of the firm.

H1.2: Long-term debt has a negative impact on the financial performance of the firm.

There are other variables which are going to be controlled in this study, that have been proven to have an impact on the profitability or financial performance of the firm, such as size and age. Based on that, the second and third hypotheses are developed as follows:

H2: Firm size has a positive impact on the financial performance of the wholesale and retail sector companies in South Africa and Sri Lanka.

H3: Firm age has a positive impact on the financial performance of the wholesale and retail sector companies in South Africa and Sri Lanka.

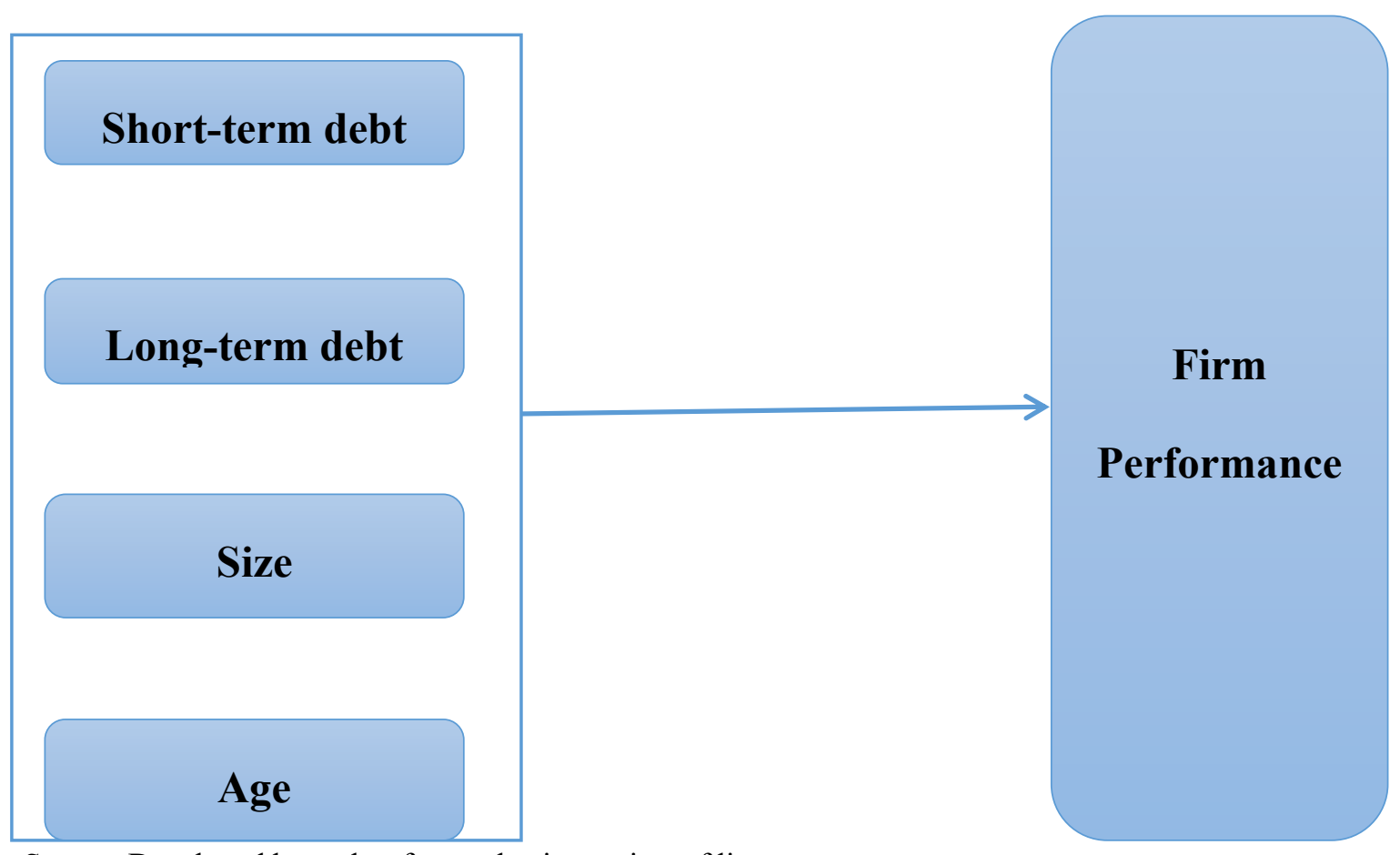

Source: Developed by author from selective review of literature

Debt ratios, in terms of short-term debt and long-term debt are expected to influence performance of the firm in terms of profitability. The literature provides empirical evidence that the outcome of the impact of debt financing, as measured by the debt ratios, on firm performance, depends entirely on the industry in which the researched firms operate as well as the region (location) in which they are based. The previous studies show mixed results with some (Mesquita and Lara, 2003; Abor, 2005; David \&Olorunfemi, 2010; Nimalathasan and Brabete, 2010; Salim and Yadav, 2012; etc.) finding positive relationships (impacts) 
while others (Gleason et al., 2000; Goddard et al., 2005; Sadeghian et al., 2012; Yazdanfar and Öhman, 2015; etc.) are showing negative results, and a few (Abu-Tapanjeh, 2006 and Ebaid, 2009) finding a weak-to no-impact relationship. Abor (2007) found that short-term debt has a positive influence on firm performance in terms of ROA, while long-term debt has a negative influence.

Based on the studies of Gleason et al. (2000) and Yazdanfar and Öhman (2015), which have analysed the wholesale and retail sector among others, debt ratios are expected to have a negative impact on the financial performance of the firm.

Theory has shown that size has a positive impact on the financial performance of the firm as the larger firms achieve and make good use of the economies of scale and that their greatness allows them to have better abilities to use technology in order to achieve larger market shares and better diversification of products, and thus profitability (Majumdar and Chhibber, 1999; Frank and Goyal, 2003;). On that note, size of the firm is expected to have a positive impact on the financial performance of the firm.

Age of the firm is another factor that has been suggested as a positive influencer of firm performance, particularly because older firms have and back themselves with the vast business experience that they have accumulated over the years. Older firms can easily avoid that type of liability due to their experience and familiarity in the market. Hence it is said that they (older firms) achieve experience-based economies as a result of their experience which has proven to be an added advantage for them. Majumdar and Chhibber (1999) built on (supported) that notion and added that the learning and business experience of older firms will enable them to gain economic advantage, and to have access to more resources and reputation effects. This generates opportunities for better performance, and this assertion was backed by Cabral and Mata (2003). On that note, firm age is also expected to have a positive impact on the financial performance of the firm.

The population of this study is defined in terms of the number of the publicly listed companies in the wholesale and retail sector as stipulated by the Johannesburg Stock Exchange (JSE) as well as Colombo Stock Exchange (CSE). According to JSE data, there are 47 publicly listed companies operating in the wholesale and retail sector. CSE has just recently adopted the Global Industry Classification Standard (GICS) which was developed by Morgan Stanley Capital International (MSCI). According to the GICS sector classification at CSE, there are 12 companies in the Consumer Discretionary sector which are classified under the Retailing industry group. There are 4 more companies classified to be operating in the Food \& Staples Retailing industry group, which fall under the Consumer Staples sector. The total population of data collected from CSE was 16 companies, and they were all considered for this research as they met the criteria for selection in this study. Data were collected from the listed companies on the JSE as well as CSE for 2011-2015 periods. The analysis is based on 25 publicly listed firms in the wholesale and retail sector from South Africa and 16 from Sri Lanka.

Using data from 2011 to 2015 period is considered reasonable as it is recent and shows relevance to this study, and most importantly to the firms operating in the researched sector. 
Another reason is that this was a period during which the companies had just come out of the recovery phase following the global recession in 2008-09; and in the case of Sri Lanka, this period followed the recovery phase that took place after the end of the civil war in 2009.

The relationship between debt capital and firm performance as well as the impact thereof was tested by the following regression models:

$$
\begin{aligned}
& \operatorname{ROA}_{i, t}=\beta_{0}+\beta_{1} \text { STD }_{i, t}+\beta_{2} L T D_{i, t}+\beta_{3} \text { Size }_{i, t}+\beta_{4} \text { Age }_{i, t}+\mu_{i, t} \\
& \operatorname{ROS}_{i, t}=\beta_{0}+\beta_{1} S T D_{i, t}+\beta_{2} L T D_{i, t}+\beta_{3} \text { Size }_{i, t}+\beta_{4} \text { Age }_{i, t}+\mu_{i, t}
\end{aligned}
$$

Where:

$S T D_{i, t} \quad=$ short term debt to total assets for firm $\mathrm{i}$ in year $\mathrm{t}$;

$L T D_{i, t} \quad=$ long term debt to total assets for firm $\mathrm{i}$ in year $\mathrm{t}$;

Size $_{i, t} \quad=$ logarithm of sales for firm $\mathrm{i}$ in year $\mathrm{t}$;

$A_{\text {ge }} e_{i, t} \quad=$ age of firm $\mathrm{i}$ at time $\mathrm{t}$, measured as the natural logarithm of thenumber of years since firm inception, as of the year of data collection; and

$\mu_{i, t}$

$=$ error term.

\section{Data Analysis and Discussion}

\subsection{Analysis of South Africa's dataset}

This section starts by presenting the results of the descriptive statistics in 4.2.1, 4.2.2 presents the Correlation analysis. 4.2.3 presents and discusses results of the Fixed-effects (within) regression model.

Table 4.1 below shows the summary of the descriptive statistics. The most important measure that shows the balance point and is the exertion center of distribution is arithmetic mean (Sadeghian et al., 2012). The sampled companies are characterized by an average age of just above 63 years. The mean age show that these companies have been in business for long and are generally well established. The mean value for company size is 9.8 . The mean values of both company size and age indicate that the sampled companies are fairly large and have reached a significant scale of operations. The ROA and ROS reveal that companies operating in this sector achieve modest profitability, with mean profitability of $8.85 \%$ and $5.52 \%$ for ROA and ROS respectively. The descriptive statistics indicate that profitability of the sampled firms (as measured by ROA and ROS) as well as long-term debt are highly volatile, as the standard deviations of these variables are greater than their mean values. However, levels of short-term debt, size and age indicate that they are less volatile, and thereby showing the quality of being similar or comparable in nature (homogeneousness) of the sampled companies.

As shown in the descriptive statistics table below, 37\% of total assets of the sampled companies were on average financed using short-term debt, while long-term debt was used as a means of financing for approximately $15 \%$ of the total assets. This means that just about 
$52 \%$ of the total assets in the sampled companies are financed by debt, and thereby revealing that companies in this sector generally use internal financial sources (i.e. equity capital and retained earnings) to finance around $48 \%$ of the total assets. The proportion between debt use and equity use is not much (approximately 4\%), and that indicates the balance of financing options maintained when using these two components of the capital structure by companies in the wholesale and retail sector, with slight preference to debt over equity. Companies in this sector seem to prefer short-term debt as their external source of financing. They use long-term debt less often or minimally. The reason for this was better explained by Yazdanfar and Öhman (2015) when the researchers indicated that 'Financial institutions such as banks usually agree to issue short-term debt, because it can be cancelled on short notice. Therefore, firms can use short-term debt as an additional funding source to increase internal sources of capital.' The mean values of all the variables are significant at 5 percent level.

Table 4.1. Descriptive statistics for the dependent and independent variables

\begin{tabular}{|c|c|c|c|c|c|c|}
\hline Variable & & Mean & Std. Dev. & Min & Max & Observati \\
\hline \multirow[t]{3}{*}{ ROA } & Overall & 0.0885 & 0.1056 & -0.2799 & 0.3312 & $N=125$ \\
\hline & Between & & 0.0986 & -0.1644 & 0.3063 & $n=25$ \\
\hline & Within & & 0.0416 & -0.0270 & 0.2823 & $T=5$ \\
\hline \multirow[t]{3}{*}{ ROS } & Overall & 0.0552 & 0.0758 & -0.1834 & 0.2278 & $N=125$ \\
\hline & Between & & 0.0728 & -0.0994 & 0.2152 & $n=25$ \\
\hline & Within & & 0.0246 & -0.0334 & 0.1770 & $T=5$ \\
\hline \multirow[t]{3}{*}{ STD } & Overall & 0.3721 & 0.9143 & 0.0985 & 0.8699 & $N=125$ \\
\hline & Between & & 0.1841 & 0.1281 & 0.7163 & $n=25$ \\
\hline & Within & & 0.0704 & 0.1676 & 0.6336 & $T=5$ \\
\hline \multirow[t]{3}{*}{ LTD } & Overall & 0.1478 & 0.1631 & 0.0109 & 0.9469 & $N=125$ \\
\hline & Between & & 0.1591 & 0.0145 & 0.8329 & $n=25$ \\
\hline & Within & & 0.0459 & 0.0064 & 0.3927 & $T=5$ \\
\hline \multirow[t]{3}{*}{ Size } & Overall & 9.8033 & 0.8625 & 7.7526 & 11.0557 & $N=125$ \\
\hline & Between & & 0.8741 & 7.8606 & 10.9615 & $n=25$ \\
\hline & Within & & 0.0668 & 9.6393 & 10.0099 & $T=5$ \\
\hline \multirow[t]{3}{*}{ Age } & Overall & 63.16 & 35.6808 & 8.00 & 130.00 & $N=125$ \\
\hline & Between & & 36.2418 & 10.00 & 128.00 & $n=25$ \\
\hline & Within & & 1.4199 & 61.16 & 65.16 & $T=5$ \\
\hline
\end{tabular}

ROA = Return on Assets; ROS = Return on Sales; STD = Short-term debt; LTD = Long-term debt; Size $=$ natural logarithm of total sales; Age $=$ Number of years since establishment.

The results of correlation analysis between the dependent variables, which are represented in terms of ROA and ROS, as well as each independent and control variable are reported in Table 4.2 below.

The results also confirm that all the coefficients between variables are fairly low, so there is no indication of multicollinearity among the variables included in the model. 
Table 4.2. Correlation of analyses of the variables included in the study

\begin{tabular}{|l|l|l|l|l|l|l||}
\hline & ROA & ROS & STD & LTD & Size & Age \\
\hline ROA & 1 & $0.862^{* *}$ & $-0.238^{*}$ & $-0.496^{* *}$ & $0.271^{* *}$ & $0.113^{* *}$ \\
\hline ROS & $0.862^{*}$ & 1 & $-0.452^{*}$ & $-0.428^{* *}$ & $0.135^{* *}$ & $0.155^{* *}$ \\
\hline STD & $-0.238^{* *}$ & $-0.452^{* *}$ & 1 & $-0.162^{*}$ & $0.282^{* *}$ & $-0.396^{* *}$ \\
\hline LTD & $-0.496^{* *}$ & $-0.428^{* *}$ & $-0.162^{*}$ & 1 & $0.143^{* *}$ & $0.237^{* *}$ \\
\hline Size & $0.271^{* *}$ & $0.135^{* *}$ & $0.282^{*}$ & $0.143^{* *}$ & 1 & $0.200^{* *}$ \\
\hline Age & $0.113^{* *}$ & $0.154^{* *}$ & 0.3955 & $0.237^{* *}$ & $0.200^{* *}$ & 1 \\
\hline
\end{tabular}

Notes: ${ }^{* *}$ Correlation is significant at 5 percent level. ROA $=$ Return on Assets;

ROS $=$ Return on Sales; STD $=$ Short-term debt LTD = Long-term debt;

Size $=$ natural logarithm of total sales; Age $=$ Number of years since establishment.

Table 4.3 and 4.4 below present the regression results using the Fixed-effects (within) regression model to test the impact of debt capital on the financial performance of companies measured by ROA and ROS. As indicated by the results of the complete model and consistent with $H 1$, debt capital - i.e. short-term debt and long-term debt - has a negative impact on firm performance in the case of both ROA and ROS. In terms of ROA, the slope coefficients of long-term debt and short-term debt are both negative and statistically significant at 5 per cent level. The slope coefficient of the long-term debt ratio variable $(\beta=-0.3663613 ; \mathrm{P}>|\mathrm{t}|=0.000)$ represents the highest debt ratio, while the slope coefficient of the short-term debt ratio variable $(\beta=-0.2283428 ; \mathrm{P}>|\mathrm{t}|=0.000)$ represent the lowest.

In terms of ROS, the results are somewhat similar with the slope coefficients of both long-term debt and short-term debt being negative and statistically significant at 5 per cent level. However, the slope coefficients of both debt ratio variables are comparatively lower than in ROA. In the case of ROS, the slope coefficient of the long-term debt ratio variable ( $\beta$ $=-0.1719025 ; \mathrm{P}>|\mathrm{t}|=0.002)$ still represents the highest debt ratio, while the slope coefficient of the short-term debt ratio variable $(\beta=-0.1188747 ; \mathrm{P}>|\mathrm{t}|=0.001)$ represent the lowest. These results suggest that an increase in the amount of both or either short-term debt and long-term debt is associated with a decrease in the financial performance of the firm.

Size of the firm is proved to have a significant positive impact on firm performance as measured by both ROA and ROS. This is consistent with H2, indicating that larger companies in the wholesale and retail sector operating in the South African market are, on average, more likely to be profitable or perform well financially. This could also mean that larger companies in South Africa are able to achieve the economies of scale and are also able to exercise considerable influence in product and factor markets. Contrary to $H 3$ put forward, the firm's age was found to have significantly negative associations with both ROA and ROS, and thus implying that younger firms tend to perform well financially than their older counterparts, as they may be flexible in adjusting or adapting to rapid changes that have been one of characteristics of this particular industry in recent years.

Overall, the empirical results in Table 4.3 and 4.4 below indicate that after controlling for factors such as firm size and firm age, debt capital (debt ratios) has a negative impact on the 
financial performance of the firms operating in the South African wholesale and retail sector in terms of profitability (ROA and ROS). Companies which have lower debt ratios appear to be performing well and are able to achieve higher profits. The evidence provided by the current study is in accordance with the pecking order theory. The empirical findings of the current study support those of previous studies from other countries and different sectors, e.g. Majumdar and Chhibber (1999), Gleason et al. (2000); Goddard et al. (2005), Abor (2007), Sheikh and Wang (2011); Salim and Yadav (2012); Dawar (2014); and Yazdanfar and Öhman (2015).

Table 4.3. Regression results of debt capital and firm performance measured by ROA

\begin{tabular}{|l|r|r|l|l|}
\hline ROA & Coefficient & Std. Err. & T-statistics & Significan \\
\hline Short term debt & -0.2283 & 0.0516 & $-4.42^{* *}$ & 0.000 \\
\hline Long term debt & -0.3664 & 0.0821 & $-4.46^{* *}$ & 0.000 \\
\hline Size & 0.227 & 0.0843 & $2.69^{* *}$ & 0.008 \\
\hline Age & -0.0158 & 0.0039 & $-4.03^{* *}$ & 0.000 \\
\hline Constant & -1.0009 & 0.6552 & $-1.53^{* *}$ & 0.130 \\
\hline$R^{2}$ Within & 0.4028 & & & \\
\hline$R^{2}$ Within & 0.0021 & & & \\
\hline$R^{2}$ Overall & 0.0029 & & & \\
\hline Sigma u & 0.5641 & & & \\
\hline Sigma e & 0.0365 & & & \\
\hline rho & 0.9958 & & & \\
\hline Prob $>F$ & 0 & & & \\
\hline
\end{tabular}

Notes: ** Significant at 5 percent level. ROA $=$ Return on Assets;

Size $=$ natural logarithm of total sales; Age $=$ Number of years since establishment

Table 4.4. Regression results of debt capital and firm performance measured by ROS

\begin{tabular}{|l|r|r|l|l|}
\hline ROS & Coefficient & Std. Err. & T-statistics & Significan \\
\hline Short term debt & -0.1189 & 0.0331 & $-3.59^{* *}$ & 0.001 \\
\hline Long term debt & -0.1719 & 0.0526 & $-3.27^{* *}$ & 0.002 \\
\hline Size & 0.1565 & 0.054 & $2.90^{* *}$ & 0.005 \\
\hline Age & -0.0089 & 0.0025 & $-3.55^{* *}$ & 0.001 \\
\hline Constant & -0.8461 & 0.4199 & $-2.01^{* *}$ & 0.047 \\
\hline $\mathrm{R}^{2}$ Within & 0.3007 & & & \\
\hline $\mathrm{R}^{2}$ Within & 0.0013 & & & \\
\hline $\mathrm{R}^{2}$ Overall & 0.0007 & & & \\
\hline Sigma u & 0.3305 & & & \\
\hline Sigma e & 0.0234 & & & \\
\hline rho & 0.9950 & & & \\
\hline Prob $>\mathrm{F}$ & 0.0000 & & & \\
\hline
\end{tabular}

Notes: ** Significant at 5 percent level. ROA $=$ Return on Assets;

Size $=$ natural logarithm of total sales; Age $=$ Number of years since establishment. 


\subsection{Analysis of Sri Lanka's dataset}

Table 4.5 below presents the summary of the descriptive statistics of both the dependent and independent variables. The Sri Lankan companies are characterized by an average age of approximately 59 years. This shows that the companies operating in the retail industry of Sri Lanka are generally old and well established in the market. The mean size is around 9.5, and thus indicating that the sampled companies are fairly and generally large. The average size and age of the sampled companies indicate that they have reached a significant scale of operations. The profits achieved by companies in this sector are not high, as shown by mean values of ROA and ROS. ROA show that companies make returns of approximately $6.7 \%$ from their investments in assets, while ROS show that they gain almost $13 \%$ from their total sales.

The statistics below reveal that the sampled companies prefer to finance their assets using more short-term debt over long-term debt. Approximately 37\% of total assets of the sampled companies were on average financed using short-term debt, while long-term debt was only used to finance approximately $7 \%$ of the total assets. The total debt financing of the Sri Lankan companies in this sector adds up to more or less than $44 \%$, which means debt as a means of financing is least preferred by Sri Lankan firms as they only use it to finance less than half of their total assets. This also indicates slight preference by the sampled companies to use internal financial sources (i.e. equity capital and retained earnings) as opposed to external funding. Funding other than external financing is used to finance approximately $56 \%$ of the total assets. Although the difference in percentages between debt use and equity use is not too high (approximately 12\%), it is clear from the descriptive statistics that Sri Lanka retail companies prefer to use internal funds more than external ones (i.e., debt financing).

Just as is the case in South African companies, Sri Lankan firms prefer to use short-term debt over long-term debt, and this could be due to the ease of access of short-term debt as opposed to long-term debt which usually has unattractive terms and conditions for businesses. The use of short-term debt is to be expected, as working capital loans are better secured and less risky than fixed investment loans (Yazdanfar and Öhman; 2015). The descriptive statistics below indicate that profitability of the sampled companies (as measured by ROA and ROS) as well as long-term debt are highly volatile, as the standard deviations of these variables are greater than their mean values. However, levels of short-term debt, size and age indicate that they are less volatile, and thereby showing the quality of being similar or comparable in nature (homogeneousness) of the sampled companies. 
Table 4.5. Descriptive statistics for the dependent and independent variables

\begin{tabular}{|c|c|c|c|c|c|c|}
\hline Variable & & Mean & Std. Dev. & Min & Max & Observati \\
\hline \multirow[t]{3}{*}{ ROA } & Overall & 0.0676 & 0.0764 & -0.0754 & 0.3605 & $N=80$ \\
\hline & Between & & 0.0510 & -0.0094 & 0.1673 & $n=16$ \\
\hline & Within & & 0.0580 & 0.0523 & 0.3013 & $T=5$ \\
\hline \multirow[t]{3}{*}{ ROS } & Overall & 0.1288 & 0.2630 & -0.1115 & 1.7566 & $N=80$ \\
\hline & Between & & 0.1815 & 0.0281 & 0.6353 & $n=16$ \\
\hline & Within & & 0.1947 & 0.3280 & 1.4363 & $T=5$ \\
\hline \multirow[t]{3}{*}{ STD } & Overall & 0.3666 & 0.1997 & 0.0231 & 0.8575 & $N=80$ \\
\hline & Between & & 0.1927 & 0.1383 & 0.7813 & $n=16$ \\
\hline & Within & & 0.0679 & 0.1475 & 0.5299 & $T=5$ \\
\hline \multirow[t]{3}{*}{ LTD } & Overall & 0.0679 & 0.6820 & 0.0037 & 0.3659 & $N=80$ \\
\hline & Between & & 0.0528 & 0.0158 & 0.2133 & $n=16$ \\
\hline & Within & & 0.0448 & -0.0274 & 0.3096 & $T=5$ \\
\hline \multirow[t]{3}{*}{ Size } & Overall & 9.5663 & 0.7612 & 8.1963 & 10.7898 & $N=80$ \\
\hline & Between & & 0.7681 & 8.3267 & 10.7105 & $n=16$ \\
\hline & Within & & 0.1391 & 9.0667 & 10.0462 & $T=5$ \\
\hline \multirow[t]{3}{*}{ Age } & Overall & 58.625 & 30.0861 & 12 & 106 & $N=80$ \\
\hline & Between & & 30.8434 & 14 & 104 & $n=16$ \\
\hline & Within & & 1.4231 & 56.625 & 60.625 & $T=5$ \\
\hline
\end{tabular}

ROA = Return on Assets; ROS = Return on Sales; STD = Short-term debt; LTD = Long-term debt; Size $=$ natural logarithm of total sales; Age $=$ Number of years since establishment.

Table 4.6 below presents the results of the correlation analysis of the variables using Sri Lanka's dataset.

Table 4.6. Correlation of analyses of the variables included in the study

\begin{tabular}{|l|l|l|l|l|l|l||}
\hline & ROA & ROS & STD & LTD & Size & Age \\
\hline ROA & 1 & $0.575^{* *}$ & $-0.041^{* *}$ & $-0.162^{* *}$ & $0.052^{* *}$ & $0.073^{* *}$ \\
\hline ROS & $0.575^{* *}$ & 1 & $-0.1444^{* *}$ & $0.162^{* *}$ & $-0.347^{* *}$ & $-0.021^{* *}$ \\
\hline STD & $-0.041^{* *}$ & $-0.1444^{* *}$ & 1 & $0.046^{* *}$ & $0.294^{* *}$ & $-0.415^{* *}$ \\
\hline LTD & $-0.162^{* *}$ & $-0.162^{* *}$ & $0.046^{* *}$ & 1 & $0.141^{* *}$ & $-0.195^{* *}$ \\
\hline Size & $0.052^{* *}$ & $-0.347^{* *}$ & $0.294^{* *}$ & $0.141^{* *}$ & 1 & $0.140^{* *}$ \\
\hline Age & $0.073^{* *}$ & $-0.021^{* *}$ & $-0.415^{* *}$ & $-0.195^{* *}$ & $0.140^{* *}$ & 1 \\
\hline
\end{tabular}

Notes: ** Correlation is significant at 5 percent level. ROA $=$ Return on Assets;

ROS = Return on Sales; STD = Short-term debt; LTD = Long-term debt;

Size $=$ natural logarithm of total sales; Age $=$ Number of years since establishment.

Table 4.7 and 4.8 below present the regression results using the Fixed-effects (within) regression model., and this is consistent with H1.1. In terms of ROA, the slope coefficient of short-term debt is negative and statistically significant at 5 per cent level. The slope coefficient of the short-term debt ratio variable is $\beta=-0.325733 ; \mathrm{P}>|\mathrm{t}|=0.004$. However, the results show that long-term debt has no statistically significant relationship and influence on ROA. The significance level of long-term debt is at $13.5 \%$ and falls outside the acceptable significance level of $5 \%$.

In terms of ROS, the slope coefficient of short-term debt is negative and statistically significant at 5 per cent level. The slope coefficient of the short-term debt ratio variable is $\beta=$ 
-0. 8790638; $\mathrm{P}>|\mathrm{t}|=0.016$. It is noticeable that the slope coefficient of the short-term debt in the model developed for ROS is quite high as compared to the slope coefficient of short-term debt in the ROA model. However, long-term debt, in contrast with H1.2, appears to have a positive impact on firm performance as measured by ROS. The slope coefficient of long-term debt is negative and statistically significant at 5 per cent level. The slope coefficient of long-term debt ratio variable is $\beta=2.352159 ; \mathrm{P}>|\mathrm{t}|=0.000$, and it's clear that it's very high. This shows that an increase in the amount of long-term debt will result in an increase in the profitability of the Sri Lankan firms operating in the retail sector, while an increase in the amount of short-term debt will lead to a decline in the firms' profitability.

In confirmation of $H 2$, size of the firm is proved to have a significant positive impact on firm performance as measured by ROA, and thereby indicating that larger companies in the Sri Lankan retail sector are, on average, more likely to be profitable or perform well financially. This could also mean that larger companies in Sri Lanka are able to achieve the economies of scale and are also able to exercise considerable influence in product and factor markets. The results of the ROS model indicate that size has no statistically significant relationship and influence of the financial performance of the firm. The significance level of firm size in the ROS model is at $34.7 \%$.

Contrary to $H 3$ put forward, and similar to South Africa's regression results, the firm's age was found to have significantly negative associations with both ROA and ROS, and thus implying that younger firms tend to perform well financially than their older counterparts, as they may be flexible in adjusting or adapting to rapid changes that have been one of characteristics of this particular industry in recent years. The relationship between all the variables and the influence of explanatory variables on dependent variables are confirmed by the 't-values' which tested the hypotheses, and the results show that short-term debt (independent variable) and the age of the firm (control variable) affect both ROA and ROS negatively. Long-term debt (independent variable) affects ROS positively, while the size of the firm affects ROA positively. The Fixed-effects (within) regression model indicate that independent variables explain approximately 34.42 percent of the change in ROA, and 37.05 percent of the change in ROS, as shown by 'R-squared' in their respective regression results. This suggests that other firm-level, industry and/or macroeconomic variables obviously affect the financial performance of the firm. Approximately $99 \%$ of the variance in the ROA regression results is due to differences across the panels, while for ROS the variance is approximately $97 \%$. This is depicted by 'rho' which is known as the intraclass correlation or the percentage of the variation that's explained by individual specific effects. The high percentage of 'rho' in the two regression results (in terms of ROA and ROS) is good as it means that it's not just idiosyncratic.

Overall, the empirical results in Table 4.7 and 4.9 below indicate that after controlling for factors such as firm size and firm age, short-term debt has a negative impact on the financial performance of the firm, while long-term impacts firm performance positively. Firm performance was measured in terms of profitability ratios (ROA and ROS), and this results are for all the Sri Lankan companies operating in the retail sector as per the GCIS classification. The results show that companies that finance their businesses using long-term 


\section{Al Macrothink}

Asian Journal of Finance \& Accounting

ISSN 1946-052X

2017, Vol. 9, No. 2

debt appear to be performing well as opposed to the ones that use more of short-term debt capital. Therefore, lower levels of short-term debt and higher levels of long-term debt can ensure better financial performance for the Sri Lankan firms operating in the retail sector.

The results of the current study, using Sri Lanka's dataset, are in contrast with the findings of Gleason et al. (2000) which studied the relationship between capital structure and performance of the retailers in 14 European countries and found that agency issues may lead to use of higher than appropriate levels of debt in the capital structure, thereby producing lower performance. Other studies that found the same results as Gleason et al. (2000) are Abor (2007); Dawar (2014); Yazdanfar and Öhman (2015), amongst others.

Table 1. Regression results of debt capital and firm performance measured by

\begin{tabular}{|l|r|r|l|l|}
\hline ROA & Coefficient & Std. Err. & T-statistics & Significan \\
\hline Short term debt & -0.3257 & 0.1084 & $-3.01^{* *}$ & 0.004 \\
\hline Long term debt & 0.2174 & 0.1435 & $1.52^{* *}$ & 0.135 \\
\hline Size & 0.1815 & 0.0472 & $3.85^{* *}$ & 0.000 \\
\hline Age & -0.022 & 0.005 & $-4.43^{* *}$ & 0.000 \\
\hline Constant & -0.2756 & 0.4968 & $-0.55^{* *}$ & 0.581 \\
\hline$R^{2}$ Within & 0.3442 & & & \\
\hline$R^{2}$ Within & 0.0096 & & & \\
\hline$R^{2}$ Overall & 0.0077 & & & \\
\hline Sigma u & 0.6439 & & & \\
\hline Sigma e & 0.0539 & & & \\
\hline rho & 0.993 & & & \\
\hline Prob $>F$ & 0 & & & \\
\hline
\end{tabular}

Notes: ** Significant at 5 percent level. ROA = Return on Assets;

Size $=$ natural logarithm of total sales; Age $=$ Number of years since establishment. 
Table 4.8. Regression results of debt capital and firm performance measured by ROS

\begin{tabular}{|l|r|r|l|l|}
\hline ROS & Coefficient & Std. Err. & T-statistics & Significan \\
\hline Short term debt & -0.8791 & 0.3563 & $-2.47^{* *}$ & 0.016 \\
\hline Long term debt & 2.3522 & 0.4718 & $4.99^{* *}$ & 0.000 \\
\hline Size & 0.147 & 0.155 & $0.95^{* *}$ & 0.347 \\
\hline Age & -0.0335 & 0.0163 & $-2.05^{* *}$ & 0.045 \\
\hline Constant & 0.847 & 1.6332 & $0.52^{* *}$ & 0.606 \\
\hline $\mathrm{R}^{2}$ Within & 0.3705 & & & \\
\hline $\mathrm{R}^{2}$ Within & 0.0009 & & & \\
\hline $\mathrm{R}^{2}$ Overall & 0.0012 & & & \\
\hline Sigma u & 1.0194 & & & \\
\hline Sigma e & 0.1773 & & & \\
\hline rho & 0.9706 & & & \\
\hline Prob $>\mathrm{F}$ & 0.0000 & & & \\
\hline
\end{tabular}

Notes: ** Significant at 5 percent level. ROA $=$ Return on Assets;

Size $=$ natural logarithm of total sales; Age $=$ Number of years since establishment.

\section{Conclusion and Recommendations}

Firms of different sizes often have one common problem, which is, deciding on whether to use debt and/or equity to finance their operations. The decision is of extreme importance given the impact it has on firm value and performance. From a managerial and owner's perspective, this financial decision requires thorough examination before it can be made. This study provides empirical evidence on that issue. The purpose of the study is to examine the impact of debt capital on the financial performance of companies operating in the wholesale and retail sectors of South Africa and Sri Lanka during a five year period, 2011-2015. The study attempted to explore the gaps in the study of capital structure in order to provide empirical evidence that could be the basis for further research and improved understanding in this field. The study also attempted to determine the extent of use of debt capital between companies in South Africa and how they compare with their Sri Lankan counterparts.

Contrary to the agency-cost theory which suggests that high leverage levels can help firms increase market value and performance, the overall results of this study indicate that debt capital, in the form of both long-term debt and short-term debt affects the financial performance of the South African firms operating in the wholesale and retail sector significantly and negatively. These results are consistent with the pecking order theory and confirm the findings of Gleason et al. (2000) and Yazdanfar and Öhman (2015) which indicated that debt financing affects the financial performance of wholesalers and retailers negatively. The results also support the most influential evidence provided by Myers (1984) against the static tradeoff theory. The study by Myers (1984) founda strong inverse correlation between profitability and financial leverage. Other researchers that have found similar results are, amongst others, Booth et al. (2001); Fama and French (2002); Goddard et al. (2005); Dawar(2014), etc. 
The results from the South African firms confirm Dawar (2014)'s suggestions that the assumptions of the agency cost theory may be commonly received and accepted in developed and other emerging markets, but this is not the case in many developing and/or underdeveloped markets. Although both short-term debt capital and long-term debt capital affect firm performance negatively in South African firms, only short-term debt capital affect the performance of the Sri Lankan retail companies significantly and negatively. Long-term debt capital of the Sri Lankan retail companies has a significant positive impact on the financial their performance. The companies from both countries seem to prioritize the use of short-term debt before long-term debt, and this could be due to the ease of access of short-term debt as opposed to long-term debt which usually has unattractive terms and conditions for businesses. As pointed out by Yazdanfar and Öhman (2015), 'Such a strategy can reduce the costs related to information asymmetry and agency conflicts. The lower the leverage level, the lower the agency costs of external debt and the higher the firm profitability.' Sri Lankan retailers seem to slightly prefer the use of internal financial sources (i.e. equity capital and retained earnings) as opposed to external funding as they use debt capitalto finance less than half of their total assets.

The size of the firm, in the case of both South Africa and Sri Lanka, has a significant and positive impact on company performances, which is a contradiction to the findings of Yazdanfar and Öhman (2015)'s study which indicated that size had a significantly negative relationship with profitability in the retail trade and wholesale sectors.

However, the size-performance relationship supports the findings of Gleason et al. (2000)'s study which indicated that firm size also influences performance, with larger retailers earning higher return on assets compared to smaller retailers. This indicates that larger companies in the wholesale and retail sector are, on average, more likely to be profitable or perform well financially than their small counterparts. Younger firms from both countries seem to be performing well financially than their older counterparts, as they may be flexible in adjusting or adapting to rapid changes that have been one of the characteristics of this particular industry in recent years. This is shown by the significant negative relationship between age of the South African firms and the financial performance of the firm. The same age-performance association is found in Sri Lankan retailers as well. This confirms the results of Warusawitharana (2014), Dawar (2014) and Yazdanfar and Öhman (2015).The researcher stated that as firms age, they tend to be more likely to transition towards being less-profitable firms.

Although the South African firms seem to be trying to balance the use of debt and equity in terms of percentage (Debt use $=52 \%$; Equity use $=48 \%$ ), the empirical evidence provided by the current study shows that the negative impact of debt capital on firm performance suggest that debt levels in these firms need to be cut down to ensure improved performances. This suggests that managers of profitable companies operating in the South African wholesale and retail sector can use equity capital and retained earnings efficiently, thereby minimizing conflicts of agency or agency costs and remaining independent of external financiers. In the case of Sri Lanka, the owners and managers of the retail companies should consider reducing the use of short-term debt and increase long-term debt capital as long-term debt seems to 
influence their financial performances positively. They can use more long-term debt capital to a point where profits are maximized and it's no longer sensible for them to issue more long-term debt.

Future research can explore and study the impact of debt capital on the financial performance of companies in other sectors individually for in-depth understanding of this impact in specific sectors. It is suggested to contribute to the literature by studying the wholesale and retail sector individually in other regions (countries) as location has proved to be a significant factor when it comes to the choice of capital structure and its impact on the financial performance of the companies.

\section{References}

Abeywardhana, D. K. Y. (2015). Capital Structure and Profitability: An Empirical Analysis of SMEs in the UK.

Abor, J. (2005). The effect of capital structure on profitability: an empirical analysis of listed firms in Ghana. The journal of risk finance, 6(5), 438-445. https://doi.org/10.1108/15265940510633505

Abor, J. (2007). Debt policy and performance of SMEs: Evidence from Ghanaian and South African firms. The Journal of Risk Finance, 8(4), 364-379. https://doi.org/10.1108/15265940710777315

Ahmed Sheikh, N., \& Wang, Z. (2011). Determinants of capital structure: An empirical study of firms in manufacturing industry of Pakistan. Managerial Finance, 37(2), 117-133. https://doi.org/10.1108/03074351111103668

Al-Tally, H. A. (2014). An investigation of the effect of financial leverage on firm financial performance in Saudi Arabia's public listed companies (Doctoral dissertation, Victoria University).

Berger, A. N., \& Di Patti, E. B. (2006). Capital structure and firm performance: A new approach to testing agency theory and an application to the banking industry. Journal of Banking \& Finance, 30(4), 1065-1102. https://doi.org/10.1016/j.jbankfin.2005.05.015

Booth, L., Aivazian, V., Demirguc-Kunt, A., \& Maksimovic, V. (2001). Capital structures in developing countries. The journal of finance, 56(1), 87-130. https://doi.org/10.1111/0022-1082.00320

Byoun, S., \& Xu, Z. (2013). Why do some firms go debt free? Asia-Pacific Journal of Financial Studies, 42(1), 1-38. https://doi.org/10.1111/ajfs.12009

Cabral, L., \& Mata, J. (2003). On the evolution of the firm size distribution: Facts and theory. The American Economic Review, 93(4), 1075-1090. https://doi.org/10.1257/000282803769206205 
Campello, M. (2006). Debt financing: Does it boost or hurt firm performance in product markets?. Journal of Financial Economics, 82(1), 135-172. https://doi.org/10.1016/j.jfineco.2005.04.001

David, D. F., \& Olorunfemi, S. (2010). Capital structure and corporate performance in Nigeria petroleum industry: panel data analysis. Journal of Mathematics and Statistics, 6(2), 168-173. https://doi.org/10.3844/jmssp.2010.168.173

Dawar, V. (2014). Agency theory, capital structure and firm performance: some Indian evidence. Managerial $\quad$ Finance, $\quad 40(12), \quad 1190-1206$. https://doi.org/10.1108/MF-10-2013-0275

El-SayedEbaid, I. (2009). The impact of capital-structure choice on firm performance: empirical evidence from Egypt. The Journal of Risk Finance, 10(5), 477-487. https://doi.org/10.1108/15265940911001385

Fama, E. F., \& French, K. R. (1998). Taxes, financing decisions, and firm value. The Journal of Finance, 53(3), 819-843. https://doi.org/10.1111/0022-1082.00036

Frank, M. Z., \& Goyal, V. K. (2007). Trade-off and pecking order theories of debt. Available at SSRN 670543. https://doi.org/10.2139/ssrn.670543

Gleason, K. C., Mathur, L. K., \& Mathur, I. (2000). The interrelationship between culture, capital structure, and performance: evidence from European retailers. Journal of Business Research, 50(2), 185-191. https://doi.org/10.1016/S0148-2963(99)00031-4

Goddard, J., Tavakoli, M., \& Wilson, J. O. (2005). Determinants of profitability in European manufacturing and services: evidence from a dynamic panel model. Applied Financial Economics, 15(18), 1269-1282. https://doi.org/10.1080/09603100500387139

Hadlock, C. J., \& James, C. M. (2002). Do banks provide financial slack?. The Journal of Finance, 57(3), 1383-1419. https://doi.org/10.1111/1540-6261.00464

Huang, G. (2006). The determinants of capital structure: Evidence from China. China Economic Review, 17(1), 14-36. https://doi.org/10.1016/j.chieco.2005.02.007

Kakani, R. K., Saha, B., \& Reddy, V. N. (2001). Determinants of financial performance of Indian corporate sector in the post-liberalization era: an exploratory study. National Stock Exchange of India Limited, NSE Research Initiative Paper, (5). https://doi.org/10.2139/ssrn.904983

Kebewar, M. (2012). The effect of debt on corporate profitability: Evidence from French service sector. https://doi.org/10.2139/ssrn.2191075

Mahmoud Abu-Tapanjeh, A. (2006). An empirical study of firm structure and profitability relationship: The case of Jordan. Journal of Economic and Administrative Sciences, 22(1), 41-59. https://doi.org/10.1108/10264116200600003 
Majumdar, S. K., \&Chhibber, P. (1999). Capital structure and performance: Evidence from a transition economy on an aspect of corporate governance. Public Choice, 98(3-4), 287-305. https://doi.org/10.1023/A:1018355127454

Mesquita, J. M. C., \& Lara, J. E. (2003, July). Capital structure and profitability: the Brazilian case. In Academy of Business and Administration Sciences Conference (pp. 11-13).

Modigliani, F., \& Miller, M. H. (1958). The cost of capital, corporation finance and the theory of investment. The American economic review, 48(3), 261-297.

Modigliani, F. and Miller, M. (1963). Corporate income taxes and the cost of capital: A correction. American economic Review, June, 433-443.

Moon, G., Lee, H., \& Waggle, D. (2015). The effect of debt capacity on the long-term stock returns of debt-free firms. Applied Economics, 47(4), 333-345. https://doi.org/10.1080/00036846.2014.959655

Myers, S. C., \& Majluf, N. S. (1984). Corporate financing and investment decisions when firms have information that investors do not have. Journal of financial economics, 13(2), 187-221. https://doi.org/10.1016/0304-405X(84)90023-0

Myers, S. C. (1984). The capital structure puzzle. The journal of finance, 39(3), 574-592. https://doi.org/10.1111/j.1540-6261.1984.tb03646.x

Myers, S. C. (1989). Still searching for optimal capital structure. Are the distinctions between debt and equity disappearing, 80-95.

Nimalathasan, B., \&Brabete, V. (2010). Capital structure and its impact on profitability: A study of listed manufacturing companies in Sri Lanka. Young Economists Journal/Revista Tinerilor Economisti, 8(15).

Nirajini, A., \&Priya, K. B. (2013). Impact of capital structure on financial performance of the listed trading companies in Sri Lanka. International Journal of Scientific Research Publications, 3(5), 1-9.

Roden, D. M., \&Lewellen, W. G. (1995). Corporate capital structure decisions: evidence from leveraged buyouts. Financial Management, 76-87. https://doi.org/10.2307/3665536

Sadeghian, N. S., Latifi, M. M., Soroush, S., \&Aghabagher, Z. T. (2012). Debt Policy and Corporate Performance: Empirical Evidence from Tehran Stock Exchange Companies. International Journal of Economics and Finance, 4(11), 217. https://doi.org/10.5539/ijef.v4n11p217

Salim, M., \&Yadav, R. (2012). Capital structure and firm performance: Evidence from Malaysian listed companies. Procedia-Social and Behavioral Sciences, 65, 156-166. https://doi.org/10.1016/j.sbspro.2012.11.105

Shyam-Sunder, L., \& Myers, S. C. (1999). Testing static tradeoff against pecking order models of capital structure. Journal of financial economics, 51(2), 219-244. https://doi.org/10.1016/S0304-405X(98)00051-8 


\section{Macrothink}

Simerly, R. L., \& Li, M. (2000). Environmental dynamism, capital structure and performance: a theoretical integration and an empirical test. Strategic Management Journal, 21(1), 31-49. https://doi.org/10.1002/(SICI)1097-0266(200001)21:1<31::AID-SMJ76>3.0.CO;2-T

Weill, L. (2008). Leverage and corporate performance: does institutional environment matter?. Small Business Economics, 30(3), 251-265. https://doi.org/10.1007/s11187-006-9045-7

Warusawitharana, M. (2014). Profitability and the Lifecycle of Firms. Available at SSRN 1568965.

Yazdanfar, D., \&Öhman, P. (2015). Debt financing and firm performance: an empirical study based on Swedish data. The Journal of Risk Finance, 16(1), 102-118. https://doi.org/10.1108/JRF-06-2014-0085

Zeitun, R., \& Saleh, A. S. (2015). Dynamic performance, financial leverage and financial crisis: evidence from GCC countries. Euro Med Journal of Business, 10(2), 147-162. https://doi.org/10.1108/EMJB-08-2014-0022 